\title{
16. The State of the State in Fiji: Some failings in the periphery
}

\section{Vijay Naidu}

The State in Fiji has sought to exert control and manage an increasingly difficult external and internal environment and has consequently undergone a transformation that has affected its capacities to mediate change and reproduce Fijian society and economy. On the one hand, there are powerful forces of globalisation that the State has limited control over, and, on the other hand, within the country, there are fissiparous tendencies that have changed the nature of society and state. Fiji's membership of the World Trade Organisation (WTO) requires compliance with rules based on a neo-liberal notion of free trade which means the loss of preferential access to a number of markets for its exports. This has consequences for the economy and employment in an increasingly restive local context where class and ethnic dynamics in politics test the capacity of the State to mediate and resolve these tendencies. The State has become ever more ethnicised, raising serious issues about its effectiveness and its legitimacy.

Several contradictory trends have been evident. With globalisation there has been a degree of 'denationalisation' (Ould-Mey 1999) of the State, but the State has acted fiercely in the interest of an emergent indigenous 'middle class', which has allied itself with the established chiefly oligarchy. While subscribing however reluctantly to market principles, competition and the 'level playing field' at the level of rhetoric and with respect to international and regional trade, the State has been an instrument of the hegemonic bloc in implementing affirmative-action policies that secure its economic position as well as provide it with legitimacy in the eyes of indigenous Fijians. The latter policies in line with the objectives of ethno-nationalists have led to the ever-increasing alienation of non-ethnic Fijian citizens who have hitherto been dominant in the mainstream economy and in the professions. The ethnicised Fijian State is not a 'weak state'. It is robust and resilient but it does have several failings: its inability to create a 'nation' out of Fiji's culturally diverse citizens; diminished capacity to nurture and enforce law and order; reduced capacity to generate 'investor confidence'; inability to resolve the outstanding land tenure problem that is jeopardising the sugar industry, in particular, and commercial agriculture in general; reduced capacity to provide social services; poor to bad governance and a lack of proactive measures to provide an enabling environment for civil society.

For good or ill, in the past two decades dominant forces in the global politico-economic system have significantly transformed the nature of global society and the place of nation-states within it. In this chapter, the experience 
of Fiji will be examined. As a small island developing state, it is exposed to changes at the global level in a much more dramatic way than larger states. However, the conditions in which Fijians find themselves have also to do with the internal dynamics of their society and the workings of their state. The post-colonial transformation of Fiji has intensified contradictions within society and state and in the complex web of relationships between them. These in turn seriously compromise the country's capacity to meet the challenges of the changing global economic and political environment. As the topic is large and complex, this chapter will limit itself to some of the more significant characteristics of the State in Fiji and its relationship with wider society, 'nationally' and internationally. It identifies a number of significant parameters to assess the 'state' of the State, followed by a more detailed discussion of each of these and concluding with a prognosis of what the immediate future might hold for Fiji.

Without privileging any of these dimensions but emphasising their interconnections, they include: a) the nature of the State; b) intensification of market-led development; c) increasing social inequality and poverty; and d) the changing global politico-economic environment. The discussion of these dimensions provides a backdrop for a commentary on what are perceived as 'some failings' of the peripheral state in Fiji. But first a story.

\section{A post-1987 coup story}

In one of the early consultations/workshops organised in Nadi by what became the Citizens Constitutional Forum (CCF) in 1993, the colourful and eloquent brother-in-law of former Prime Minister Ratu Sir Kamisese Mara and a claimant of the paramount chiefly title of Rewa and the confederacy of Burebasaga, ${ }^{1}$ the late Ratu Mosese Varasikite Tuisawau, remarked on the peculiar nature of the Fijian republic. ${ }^{2}$ He pointed to the absence of people's sovereignty in the republic as the decision to cease connections with the Crown was made by Lieutenant Colonel (later self-promoted to Brigadier General) Rabuka and his Taukei advisers. He noted that the Fijian flag remained the same, with the Union Jack in its top lefthand corner. He observed that Fijian money, including the latest \$20 notes, had the Queen's head on them and not that of the President of the Republic. He went on to openly accuse his brother-in-law of complicity in the May 1987 coup: 'I have nothing to fear as I am guilty of nothing, only guilty people run from their own shadow,' he said. He saw Rabuka as an instrument of the chiefly establishment and its allies to maintain themselves in power.

I begin with this story to highlight the continuing contradictions of the Fijian republic's outward symbols and to provide my point of entry into my characterisation of the Fijian State as a 'schizophrenic state' deeply imbued with racialism, unable to pursue nation-building and the national interest but faced with very real challenges that emanate from wider society and its linkages with 
the still broader world economy. The victory of the Dr Timoci Bavadra-led Fiji Labour Party and National Federation Party Coalition over the governing Alliance Party, which had ruled the country since 1970, reflected an erosion of the ethnic politics of the post-colonial era. Socioeconomic processes had led to greater social inequality and poverty as well as a growing perception that those who were in economically and politically powerful positions were enriching themselves at the expense of the broad masses of Fiji's people. There were two types of response to these changes: one that saw them through ethnic lenses, which triggered an ethno-nationalist response; and the other that understood them as creating cleavages between 'the haves and the have-nots' in Fijian society. Peripheral capitalism generated vertical and horizontal asymmetries. The hegemonic bloc with the chiefly establishment at its heart had relied on ethnic divisions to maintain its hold on the State, and this strategy was now being threatened by class-based politics.

\section{The nature of the Fijian State}

The post-colonial State in Fiji inherited from its colonial progenitor its territorial boundaries, its institutional ensemble and above all its class, ethnic, gender and regional nature. The latter reflected the ownership and control of land and capital and the racial system of power and privilege of the colonial social order. Ideologically, this was represented by the notion of the paramountcy of Fijian interests and its protection by chiefs and Europeans. The established hierarchy had been challenged and even severely tested at various times in the 96 years of colonialism but, through a process of selective coercion, ethnic and religious appeal and cooptation, it survived intact. Resistance and rebellion had come initially from ethnic Fijians outside the Christianised eastern and central regions incorporated in the system of 'indirect rule' (Durutalo 1986; Routledge 1985) and, from the second decade of the 20th century onwards, emanating from these regions but extending Fiji-wide as indigenous Fijians sought through the Viti Kabani to exert greater control over the mercantilist colonial trading system and their lives. At the economic and later the political level, Indian and Indo-Fijian workers and farmers periodically challenged the dominant order, reinforcing their position as the 'Other' and the hegemonic alliance of dominant Europeans and eastern chiefs (Gillion 1977; Durutalo 1986). In the post-colonial period, the composition of the hegemonic bloc changed with eastern chiefs and Europeans accommodating some commoner Fijians, general voter elements and Indo-Fijian capitalists (Sutherland 1992). Needless to say, state power was and is wielded by men and manifests the patriarchal character of Fijian society.

On three occasions, in 1959, 1987 and 2000, the hegemonic bloc was severely tested and elements within it resorted to open violence. The first happened during a strike by oil and general workers when ethnic Fijian, Indo-Fijian and mixed-race workers sought higher wages. They rioted, attacking European 
property and people after the police had tear-gassed and baton-charged them. The second event followed the victory of the coalition of National Federation (NFP) and Fiji Labour (FLP) Parties against the Alliance Party in 1987. These two events featured the working people of Fiji acting as a 'class for itself' in an effort to change the balance of power. The ruling class in Fiji has been most mindful of such unity of purpose and has successfully resorted to the use of ethnicity to keep workers divided. The Alliance Party adopted a 'strategy of facing both ways, uttering multi-racial mumbo-jumbo to the electorate at large, particularly to the Indo-Fijian audience, while reiterating the paramountcy of Fijian interest to an indigenous audience' (Durutalo 1986: 31).

Ironically, the failure to deal with the substantial economic disadvantage faced by ethnic Fijians as a consequence of policies of 'separate development' resulted in Butadroka and his Fijian Nationalist Party (FNP) outbidding the 'multiracial' Alliance Party and contributing to its defeat a decade earlier in $1977 .^{3}$ A 'palace coup' by the Governor-General and his European advisers ensured the return to power of the defeated Alliance Party. ${ }^{4}$

In 1999, the two-year-old 'new' Constitution's electoral system, divisions among ethnic Fijian political parties and bad governance by the Soqosoqo ni Vakavulewa ni Taukei (SVT) Government resulted in the landslide victory of the Peoples Coalition. ${ }^{5}$ This constituted a significant challenge to the hegemonic bloc which was further rattled by the choice of an Indo-Fijian militant trade unionist as Prime Minister. As in 1987, elements of the defeated dominant ethnic Fijian party immediately set about intriguing to shorten the life of the Government, but there appeared to be a wider acceptance of the Government as it was backed by the President, the last surviving paramount chief of the eastern triumvirate. ${ }^{6}$ The putsch and coup of 2000 was the expression of a complex combination of narrow ethno-nationalism, fragmentation and power plays in the eastern chiefly component of the hegemonic bloc, opportunistic manoeuvring by an aspirant class of ethnic Fijians, attempts to secure their financial interests by Indo-Fijian and 'other' businessmen previously patronised by the State, disorder created by disaffected youth, and the failure of the Labour-led coalition to effectively deal with its opponents. ${ }^{7}$

In the past five years, society and state in Fiji have become further divided and fragmented. Routledge, in the epilogue of his book Matanitu, wrote that '[p]olitical leadership has been in the hands of the great chiefs, but when Ratu Mara leaves the prime ministership, it is unlikely that a single person will again combine high traditional status with high political office' (1985: 221). However, his observation that chiefly tradition will be a cohesive force, 'giving life and strength to Fijian society in the multicultural complexities of the contemporary state, and the region beyond' appears to have been overly optimistic. Chiefly hegemony has been jeopardised with the divisions between and within 
confederacies, the vying for power among 'younger' chiefs, widespread disputes over succession to chiefly titles, and the machinations of 'middle-class' ethnic Fijians who have used affirmative action policies to acquire wealth, power and influence for themselves (see Ratuva 2000, 2002; Tuimaleali' ifano 2000; Fraenkel 2000; Fry 2000; Lal 2003). Non-ethnic Fijian owners of capital remain influential but recognise the uncertainties that arise from the fragmentation among ethnic Fijian elements of the ruling class. There has been a continuing flight of capital from Fiji since 1987.

\section{State institutions and ethnicity}

Separate development of the 'races' in Fiji was a keystone of colonial policy. Indirect rule was backed by a Department of Native Affairs, renamed the Department of Fijian Affairs in the 1960s. A Native (now Fijian) Affairs Board was at the apex of the separate administration and worked in tandem with the Great Council of Chiefs, provincial and tikina councils. The intention was to 'preserve the traditional Fijian socio-economic order with its emphasis on communal values, reciprocal exchange and obligations of commoners to their chiefs. ... The effect, as opposed to the intention, was to place Fijians at a disadvantage in the face of changes that were inevitable as capitalism with its emphasis on individuality rather than communality penetrated the social order more completely' (Routledge 1985: 218-19). Ethnic Fijians were ruled and represented by their chiefs. They did not vote until 1963, just seven years before the country's independence. The Native Land Trust Board and related Native Commission had and has purview over land reservations, leaseholds and rent collection and distribution as well as responsibility for the adjudication of disputes over chiefly titles and landownership. Although indigenous landowning groups owned more than 83 per cent of the land, they had little to do with the negotiation of rent and how the proceeds from the leasing of their land were apportioned. The Fijian military evolved over time as largely an exclusively ethnic Fijian institution to underwrite chiefly power.

The late Rev. Paula Niukula, a former President of the Methodist Church to which most ethnic Fijians belong, described how there were close interconnections between the vanua (or community), the lotu (Christianity) and the matanitu (the Government/the State). In the perception of indigenous Fijians, these entities overlap and are mutually reinforcing.

These exclusive ethnic Fijian institutions in the State (including state-funded schools) and the Methodist Church embody 'Fijian interests' that seek to maintain ethnic Fijian solidarity and paramountcy. ${ }^{8}$ The presence of Indo-Fijians provides a significant force in manufacturing institutional and ethnic solidarity. In wider society, the Methodist Church has played a critical role in the maintenance of chiefly hegemony, ethnic Fijian identity and in-group/out-group divisions. ${ }^{9}$ The church is a strong advocate of making Fiji a 'Christian' state and was behind 
the 'Sunday Sabbath' decree in 1987. Generally, these institutions operate on the basis that they exist to protect and promote the special place of the I-Taukei ${ }^{10}$ in the country. They constitute in many ways the institutional basis of ethno-nationalism as denoted by the precept 'noqu vanua, noqu Kalou' (my land, my God). ${ }^{11}$ This narrow nationalism has severely undermined the emergence of a broader nationalism incorporating all ethnicities in the country.

The presence of these 'state within the state' institutions also generates several issues. At the level of local government there is the obvious matter of duplication. There are rural advisory boards and town councils which also have the remit of local-level decision-making and the provision of services. Although the presence of a separate Fijian administration has been questioned, it remains intact to this day. Attempts to reform what has been perceived as a system of top-down administration and patronage inimical to ethnic Fijian progress have thus far been unsuccessful. The Native Land Trust Board's leadership sought to end leasing agricultural land under the Agricultural Landlord and Tenant Act and has seriously undermined agricultural production. In the post-1987 period, the military expanded to more than 6,000 and its budget increased from \$F12-13 million to more than $\$ F 50$ million. The desecration and burning of temples, mosques and Catholic churches can be attributed to overzealous Methodists.

Besides requiring scarce state funds, some of these institutions also make direct demands on ethnic Fijian resources. Levies have been imposed on ordinary ethnic Fijians to raise funds for provincial projects. Such funds, supplemented by subventions from the State and from private banks, have been used to purchase equity in investments in provincial companies, Fijian Holdings Limited and in urban real estate. According to Ratuva (2000), these forms of 'communal capitalism' favour chiefs and their families as well as elements of the 'emergent middle class' rather than rank-and-file Fijians, who see little or no benefit from their 'investments'. Much the same can be said of the periodic fundraising efforts of the Methodist Church with the use of the funds unquestioningly left to the top echelons of the church.

As a result of these vakavanua and vaka misonari demands, ethnic Fijians find that they have limited capital for individual enterprise. This is reinforced by the lack of collateral to borrow from private banks and the competition from those who are better established in the marketplace. Invariably these include non-indigenous Fijian individuals and businesses.

\section{State functions}

Fiji, like other post-colonial states, has coercive, ideological, political and economic dimensions. The State's law and order role is supposed to guarantee property rights and individual safety, the settlement of civil disputes and the enforcement of contracts. Antecedent customary laws and practices are recognised 
by the State. The rule of law facilitates economic activities, as do fiscal and monetary policies adopted by the State. Money supply, the value of currency, exchange rates with foreign currency, import and export duties, tariffs and taxation regimes are the prerogative of the State. The State in Fiji has been an initiator of private-sector development. The origins of the Fiji Trade and Investment Board lie in the Commercial Investment Committee established in the 1970s. Incentives for business, the promotion of human resource development, and infrastructural development have been part of this facilitation process. When private investment has not been forthcoming, the State has become directly involved in capitalist enterprise. This is evident in the sugar and airline sectors as well as in the network of parastatals that were established to operate telecommunications, ports, airports and the provision of services. Besides state capitalism, the State has become a significant source of finance through entities such as the Fiji National Provident Fund, the Reserve Bank and the Development Bank. The State also acts as the arbiter in disputes between labour and capital.

Thus the State has a pivotal role in the development process. While privatisation and deregulation are modifying its multiple and complex interventions, the centrality of the State in Fiji is beyond doubt. What is in doubt, however, is its continuing effectiveness in promoting the wellbeing of all citizens and its effectiveness in meeting contemporary challenges. State capacity in this regard is reflected by state power-holders and the bureaucracy.

\section{State personnel}

At the highest levels of the post-colonial State, ethnic Fijians, usually of chiefly rank, took over from British officials. In governments between 1970 and 2004, cabinets comprised between 70 and 90 per cent ethnic Fijians (Fraenkel 2004: 14). Many of these individuals graduated from the Public Service into politics. On the two occasions when there was a more ethnically proportional representation at this level, in 1987 and in 1999, with Indo-Fijians in cabinet at 50 per cent and 33.3 per cent respectively, campaigns of destabilisation were initiated by ethnic Fijians displaced from political leadership. ${ }^{12}$

In the State bureaucracy, from near parity between ethnic Fijians and Indo-Fijians in the early 1980s, the number of Indo-Fijian public servants has declined. 'By $2000 \ldots$ ethnic Fijians accounted for $62 \%$ of civil service jobs, and were particularly over-represented in the senior ranks (91\% of permanent secretaries, $86 \%$ of Deputy Secretaries, $82 \%$ of chief administrative officers)' (Fraenkel 2004). The 1990 Constitution stipulated the reservation of the positions of President, Prime Minister, certain other ministerships, the positions of military commander and police commissioner as well as no less than 50 per cent of all public service positions for ethnic Fijians and Rotumans. In post-coup Fiji, political loyalty, ethnicity, provincialism and cronyism became the primary 
criteria for appointments and promotions in the Public Service and the police force rather than merit. There has been a militarisation of the Public Service as senior military personnel have secured positions at the level as commissioners of divisions and as district officers. For a period after the second 1987 coup, the judiciary was also compromised by doubtful appointments.

With the politicisation and ethnicisation of state personnel combined with affirmative action policies and hate speeches by the ruling Soqosoqo Duavata ni Lewenivanua (SDL) Party politicians, the perception of non-ethnic Fijian citizens is that the 'Government and its apparatuses' do not serve their interests. State rituals such as Fiji Day, Reconciliation Week and Ratu Sukuna Day have been primarily ethnic Fijian events.

Besides the initiatives to placate and even reward ethnic Fijian agitators after the 2000 coup, the Qarase Government introduced a Ministry of National Reconciliation to promote harmony among ethnic Fijians first and then inter-ethnic tolerance with Indo-Fijians and other minorities. Needless to say, for the latter the hollowness of the appeals for forgiveness and moving on were clearly evident in the very concrete steps being taken by state power-holders to divert state resources primarily to ethnic Fijians who were responsible for Fiji's troubles. Herein lies a fundamental contradiction of the State: is it a state that acts in the national interest which has to be an amalgam of the interests of all classes and ethnicities, or will it work in the interest of the politically dominant ethnic group?

The quality of public services, including the provision of utilities such as water, has been declining. Standards of health and educational services have dropped as have police services. On an annual basis, the Auditor-General's Office reports on a litany of inefficient uses of public funds, of tendering processes that are less than transparent, of outright misappropriation of funds and open abuse of office. Very few of these cases are investigated and fewer still lead to prosecution. In this context, it is noteworthy that where the Government or powerful individuals in the Public Service wish to take punitive measures against a public servant for 'political purposes', the Public Service rule books are fully utilised. The very public action against the military commander recently for overspending is a case in point.

This case reveals divisions and tensions between departments and sections of the State apparatus itself. Some of the tensions relate to resourcing issues and the power of the Ministry of Finance to override other sections. The antagonism between the military commander and the Government relates to the Promotion of Reconciliation, Tolerance and Unity Bill. While the Commissioner of Police also expressed his opposition to the bill and was asked to not make public statements about it, the military commander refused to accept directives from the Minister of Home Affairs on this matter and firmly asserted his right to speak 
directly to the President of the country. The commander, who survived the mutiny in November 2000, is single-minded about ensuring that all those who broke the law in the putsch, hostage-taking, riots, killings and mutiny are brought to justice. The Government, which came to power on the back of these manifestations of the breakdown of law and order, sees them as a reflection of indigenous Fijian political uprising. The bill has some support among ethnic Fijians and the Methodist Church, however, other ethnic Fijians have joined nearly all other citizens to oppose the bill.

From the mid-1980s powerful core countries of the world politico-economic system generated the idea that the State should not be involved in business and that the private sector must be given primacy in generating growth. Market-centred economic growth has become the dominant development paradigm in the 1990s. In Fiji, the period of relatively authoritarian rule from 1987 to 1992 also allowed the intensification of market-based reforms begun in the mid-1980s.

\section{Intensification of market-led development}

To counter the severe economic downturn after the coups, the widespread loss of jobs and the more than 30 per cent devaluation of the Fijian dollar, efforts at restructuring the economy by instituting 'painful reforms' were undertaken. These included a stronger emphasis on private sector-led export-oriented manufacturing, promotion of tourism investment, corporatisation, tax reform and labour market reform. Import substitution and tariff protection approaches that centred on the domestic market and building 'local industries' were displaced by giving freer rein to market forces to make local industries more competitive and export orientated. The periodic advice of the IMF was taken seriously and production for exports became the 'centrepiece of the new strategy'. Measures were introduced such as 13-year tax-free incentives and subsidised infrastructure to promote tax-free zones and tax-free factories. 'Within a year manufacturing was emerging as a substantial contributor to export earnings, especially in the garment sector. More than 11,000 jobs were eventually created and by the end of 1991, tax free factories were selling goods overseas worth about $\$ 200$ million. It was one of the most dramatic structural changes in the Fiji economy' (Mara 1997: 217).

Firm political commitment to facilitate tourism development and to provide incentives for investment in this sector saw significant new investment in Denarau Island near Nadi of up to $\$ 300$ million by EIE, a Japanese company. Several other resort investments were under way on outer islands.

State-owned enterprises were subjected to market-based principles such as improved efficiency, profitability and accountability to customers. Post and Telecommunications, Ika Corporation, the Fiji Pine Commission and the National 
Marketing Authority were corporatised. Corporatisation and privatisation have continued into the post-2000 period. FINTEL, a profitable state-owned enterprise, was sold by the SVT Government to obtain funds to cover the financially insolvent National Bank. The Fiji Electricity Authority has been split into three separate companies.

Taxation reforms have included the simplification of the tax regime, raising the tax threshold, reducing tax for the highest- and lowest-income categories and, most importantly, the introduction of the Value Added Tax (VAT). The latter began at 10 per cent with promises that the price of goods and services would not rise as tariffs would be brought down by a similar percentage. Opposition to the imposition of this regressive tax was countered by the provision of a $\$ 7$ million poverty alleviation fund that would see increased spending on the poor. Once the VAT came into force, prices increased and a majority of the poor did not benefit from the poverty alleviation fund, which dried up after three years. While VAT expanded the tax base beyond the 20 per cent who used to pay the pay-as-you-earn tax and the company tax, it burdened sections of the community least able to cope with increased costs of basic foodstuffs. VAT was further increased to 12.5 per cent.

Labour market reforms included the disciplining of the labour movement - an end to the check-off system for the payment of union membership fees, government scrutiny of elections of union office-bearers and voting for industrial action. Unions were no longer exempt from damages caused by disputes and members could withhold their contributions if they disagreed with the actions of the union leadership. Measures were instituted to restrict individuals from being in the executive of more than one union. In taking these measures, the State acted to reduce the bargaining power of unions generally and encouraged a movement away from broad-based multi-sector unions to enterprise-based unions. The earlier tripartite forum of government, employers' and workers' representatives was replaced by a new forum, the National Economic Summit (NES). State power-holders maintained that the meetings of the NES allowed wider consultation, beyond unionised workers, to non-unionised workers, farmers and rural dwellers, employers and social welfare groups.

\section{The State and affirmative action}

Ethnic Fijians as a general rule have been resource rich and cash poor. Their participation in the mainstream economy was previously mediated by chiefs and the Colonial Administration. Efforts at reforming the Fijian Administration and the nurturing of entrepreneurship have been limited. Despite several projects and programs during the post-colonial period, there are very few ethnic Fijian businesses or businesspeople. Post-coup governments have redoubled their efforts to address this disadvantage. In this regard, the State contributes to the 
higher-status lifestyles of state power-holders and facilitates the accumulation of wealth by them and their associates in wider society.

The Ratu Mara-led interim government (1988-91) adopted a nine-point plan in addition to the existing provisions for ethnic Fijian education, rural development, cooperatives and village development to foster equity and savings. Fijian Holdings Limited (FHL) was loaned \$20 million to buy shares in established successful companies. FHL was formed in 1984 by Fijian provinces as an investment company. With the additional funds, FHL equity in large near-monopoly companies, such as Standard Concrete and Carlton Brewery, increased significantly with improved returns on investment. Two classes of shares existed in FHL, an A class and a B class. The former were sold to selected ethnic Fijians, who could borrow investment funds from the Fiji Development Bank, and the latter category were held by provinces. FHL has been embroiled in controversy as it is seen as a vehicle for a group of elite ethnic Fijians to acquire wealth on the back of other Fijians (see Ratuva 2000). Subsequently, the SVT Government decided to make the FHL loan into an outright grant.

Ethnic Fijians also received support in investing in the Unit Trust of Fiji. Individuals and provinces constituted 58 per cent of unit-holders by the end of 1991. The Fiji Development Bank maintained its role in assisting ethnic Fijians in business. 'For three years from 1989 loans amounting to $\$ 45.4$ million were approved for 3,532 Fijians' (Mara 1997: 221). The bank's Emicol store project to build commercial acumen among selected ethnic Fijians was instituted at this stage.

From 1991 to 1999, these affirmative-action programs were continued and expanded. The SVT Government purchased a sizeable track of farm land from the Chairman of the Fiji Development Bank and FHL for the inflated price of \$7 million on which to train ethnic Fijian youth in commercial farming. Rabuka had appointed Vasanti Makarava as the CEO of the National Bank of Fiji and he saw his task as supporting ethnic Fijians and Rotumans seeking loans. Unsecured and poorly documented loans were provided and some bank employees systematically siphoned off funds for themselves, while others arranged kickbacks. The bank became insolvent with a loss of $\$ 220$ million. The defaulting borrowers could be listed in a Fijian 'Who's Who'!

After the appointment of the 'caretaker' government led by Qarase, a 'blueprint' for Fijian development was endorsed by the Great Council of Chiefs. A further $\$ 20$ million was allocated to this end. Provision was made for a separate building for the chiefs and a permanent secretariat; \$3 million was allocated to FHL. The caretaker government converted itself into the SDL Party, successfully contesting the 2001 general election. Before the elections, a generous and highly irregular distribution of a range of tools for ethnic Fijian and Rotuman development was made. These ranged from gardening forks to boats, brush-cutters to computers 
and bicycles. Many of these items were purchased at highly inflated prices from hardware stores, including those owned by Indo-Fijians. Since then an 'agricultural scam' has been uncovered involving the sum of \$30 million.

Affirmative action continued with the SDL regime's adoption of a '50/50 by $2020^{\prime}$ plan to increase ethnic Fijian participation in the mainstream economy. It is apparent that the primary beneficiaries of grants and soft loans have been a relatively small group of ethnic Fijians who have become shareholders either directly or indirectly in established companies. Especially favoured are individuals and their families who have A-class shares in FHL. 'Communal capitalism' has enriched some chiefs and an aspirant middle class, but has not changed the situation of most ethnic Fijians. Indeed, income distribution has remained highly unequal. Political instability and the constitutional impasse, reduced investor confidence, mismanagement of public funds, inappropriate policies and ineffective policy implementation have resulted in economic stagnation and lack of employment opportunities. A good 20 per cent of land formerly under sugar cane is no longer cultivated. Farming families have become squatters in and near urban centres. Politicians and the Native Land Trust Board continue to squabble over appropriate legislation to govern land leases as farming becomes an increasingly unattractive livelihood for younger people.

\section{Increasing social inequality and poverty}

Rural livelihoods have ceased to be a drawcard for some time in Fiji, however, urban formal-sector jobs have not been increasing at a rate to absorb the 17,000 school-leavers each year. Only 1,500 to 2,000 jobs are available annually for them. The presence of large numbers of unemployed puts downward pressure on wage levels, especially for unskilled and semi-skilled labour. It is little wonder that the Fiji Poverty Report found that 86 per cent of Fiji's poor (based on out-of-date surveys) were the working poor. Income distribution is skewed heavily in favour of business, the professions and the salaried. Agricultural, garment factory, construction and transport workers, clerical and retail employees, security guards and even police personnel constitute more than 40 per cent of the poor in Fiji. Destitutes include deserted women with children, street children, urban unemployed youth, dependent elderly, the disabled and the chronically sick.

As in other Third World countries, Fiji has experienced a boom in the informal sector. Activities range from the legal to the illegal: backyard workshops, home-based craft work, tailoring, food preparation, roadside stalls, barbecue stands, hawking of wares, passenger transport services, shoe shining, grass cutting, bottle collecting, the growing, processing and selling of drugs, bootlegging and prostitution. Central and local government regulations have not facilitated these people's entrepreneurial activities. 
As social inequality has increased and the sense of community has diminished during a generation, the State's capacity to resolve law and order problems has been seriously challenged. The extra-legal overthrow of duly elected governments and the immunity given to those responsible appear to have emboldened others to bend and break the law. There is an ethnic dimension to the law and order problem. It is evident that there is 'structural violence' against young people and ethnic Fijian youths react to it by externalising their sense of deprivation. Their victims have been largely Indo-Fijians. The latter tend to internalise their feelings of inadequacy and frustration. This is reflected in higher levels of psychosomatic illnesses and suicides. With opportunities of employment severely limited and, for those in employment, wage levels too low for decent living, relatively large numbers of Fijians have sought opportunities abroad.

\section{The changing global politico-economic environment}

At the political level, the collapse of the Soviet Union has provided almost infinite scope for private wealth accumulation on a world scale. There has been a rampant push to open markets for capital, goods and services by corporations backed by powerful G7 states. The Soviet collapse has also reduced the strategic significance of small island states in the South Pacific and their bargaining power. Always open and 'export-import' orientated, Pacific Island states have relied heavily on tariff charges as the major source of public revenue. Fiji, with a relatively large private sector, also had the luxury of extracting funds through income and company taxes. The thrust towards free trade is compelling Fiji and other Pacific states to rapidly reduce tariffs. Fiji became a founding member of the WTO and is a signatory of regional free trade agreements such as PICTA and PACER. With other Pacific ACP member countries, Fiji is negotiating an Economic Partnership Agreement (EPA) with officials of the EU.

In the short to intermediate term, there are few prospects for Fiji to make substantial gains from these free trade agreements. Indeed, with the erosion and loss of preferential market access to the EU, Australia, New Zealand, the USA, Japan and Malaysia, the Fijian economy is likely to continue in a downward spiral. It is intriguing, therefore, that Fiji joined the WTO so early in the piece. Professor Jane Kelsey, in her article 'World Trade and Small Nations in the South Pacific Region' (2005), which provides many insights into the accession process and the unrealistic demands on small vulnerable economies, quotes a senior Fijian state official explaining the country's WTO membership:

The question of why Fiji joined the WTO has been raised many times. The answer, put simply, is that Fiji has no choice. While the rules of the game are not always fair and the playing field is not always level, we must make efforts to become part of the process that influences and addresses both advantages and shortcomings of the current strategy of globalisation. It is important to recognise that behind every challenge, 
there is an opportunity. Adopting a head-in-the-sand response to globalisation will not permit us to avoid its impacts but means missing out on the opportunities it offers ... Never before has open trade with the international community done so much to lift the living standards and increase opportunities; yet never before has the persistence of poverty and exclusion been so glaring in most of our societies. (Fiji's Permanent Secretary for Foreign Affairs and Trade cited in Kelsey 2005: 258)

The impending curtailment of multilateral and bilateral non-reciprocal trade agreements spells a major disaster for Fiji. Under the Cotonou Agreement between the ACP group of countries and the EU, the high price paid for Fijian sugar, in the order of two to four times world market price since the early 1970s, will be phased out. Australia, Brazil and Thailand have formally lodged a joint complaint with the WTO against the EU for its differential treatment of ACP countries.

Two industries on which a very large number of people depend for their livelihoods are beginning to unravel. As Stewart Firth points out,

A second preferential trade regime that originated in the 1970s expired in 2005. This is the Multi Fibre Arrangement (MFA), which gave Fiji an export quota for garments exported to the USA. Within a few months of the end of the MFA a major garment manufacturer in the Fijian town of Lautoka closed with the loss of 3,000 jobs, and, as a consequence, the Fiji government revised its growth predictions for the economy sharply downwards, from the $3.8 \%$ achieved in 2004 to $1.5 \%$ in 2005 and $0.7 \%$ in 2006. Fiji's Prime Minister Laisenia Qarase saw 'a chill wind blowing from the direction of the World Trade Organisation. The unrealistic policies of the WTO have created a crisis in our garment industry, which provides employment for many Fiji people. Because the US must conform to WTO rules we no longer have assured entry into that market for our garments ... If this is globalisation, then it is fatally flawed. It is making a mockery of our efforts to reach national standards of governance we have set for ourselves and which the international community expects of us.' If Fiji lacked export markets, Qarase said, 'we will face an increased danger of instability, social breakdown and higher crime rates'. (Firth, pers. comm. 2006)

The people of Fiji have not waited for state power-holders to extract Fiji from its impending difficulties. They have sought opportunities for employment in the 'globalising world'. Ironically, employment opportunities have been generated by the 'war on terror' of the US and its allies. I have been informed by a former British soldier that there are a couple of thousand ethnic Fijians in the British Army. There are also several hundred employed by private security agencies in Kuwait and Iraq. Other 'migrant workers' include Fijians who provide 
care-giving services in the US mainland and who work in the health sector in Australia and New Zealand. There are smaller numbers employed in Micronesian health services. In addition, Fiji continues to provide peacekeeping soldiers and police to the UN, with contingents in East Timor and the Middle East. Remittances from labour migrants have been increasing, with the Reserve Bank of Fiji estimating figures in access of $\$ 300$ million each year. Opportunities for employment overseas, however dangerous, will become attractive as employment prospects within Fiji remain stagnant and even decline.

\section{Conclusion}

The Fijian State has ethnic, class, regional and gender dimensions. During the post-colonial period, the hegemonic bloc led by ethnic Fijian chiefs has shown increasing signs of disintegration as there is intense rivalry for power among a younger generation of the aristocracy. State personnel represent predominantly one ethnic category and appear to be committed to the 'paramountcy of Fijian interests' which entails ethnic Fijian political primacy and affirmative action designed to enrich a minority of indigenous people. This means that the State's ability to pursue the 'national interest' is seriously compromised.

With the moves to comply with WTO rules, the State's capacity to generate revenue will be seriously affected as the Fijian economy undergoes shifts away from the sugar and garment industries. It is likely that in the immediate future inequality and poverty will be further aggravated as unemployment escalates. Given the tendency of the State and political leaders to give primacy to ethnic explanations, it is possible that the predicated social unrest and political instability will yet again take ethnic dimensions.

Most Fijians understand very well the current predicament and what the foreseeable future holds for them in the country and have sought employment opportunities abroad. Remittances, with tourism, might save the day for Fiji but the general prognosis for a vibrant multi-ethnic country is not favourable and will require a profound change in the approach of state power-holders and their allies.

\section{References}

Ali, A. 1980. Plantation to Politics. Suva: University of the South Pacific.

Amuwo, K. 2002. Globalisation, NEPAD and the Governance Question in Africa. www.codesria.org/Archives/Past\%20events/ programme_for_the_governance_ins.htm

Asian Development Bank. 1995. Governance: Sound Development Management. Manila.

Burns, A. 1960. Fiji. London: HMSO. 
Dauvergne, P. (ed.) 1998. Weak and Strong States in Asia - Pacific Societies. Canberra: Allen \& Unwin and ANU.

Doornbos, M. 2001. 'Good Governance: The Rise and Decline of a Policy Metaphor.' Journal of Development Studies, 37, 6. pp. 93-108.

Durutalo, S. 1986. 'The Paramountcy of Fijian Interest and the Politicisation of Ethnicity. South Pacific Forum', Working Paper No. 6. Suva: USP Sociological Society.

Firth, S. 2000. 'The Pacific Islands and the Globalisation Agenda.' The Contemporary Pacific, 12, 1.

Firth, S. 2005. 'The Impact of Globalisation on the Pacific Islands.' Paper presented at Second South-East Asia and the Pacific Subregional Tripartite Forum on Decent Work, ILO, Melbourne, April 5-8.

Fraenkel, J. 2000. 'The Clash of Dynasties and the Rise of Demagogues; Fiji's Tauri Vakaukauwa of May 2000.' Journal of Pacific History, 35, 3. pp. 298-308.

Fraenkel, J. 2004. 'Regulating Bipolar Divisions; A Case Study of Ethnic Structure, Public Sector Inequality and Electoral Engineering in Fiji'. Suva: PIAS-DG, University of the South Pacific.

Fry, G. 2000. 'Political Legitimacy and the Post-colonial State in the Pacific: Reflections on Some Common Threads in the Fiji and Solomon Islands Coups.' Pacifica Review, 12, 3. pp. 298-304.

Ghai, Y. 1983. 'Constitutional Issues in the Transition to Independence.' In R. Crocombe and A. Ali (eds), Foreign Forces in Pacific Politics, Suva: University of the South Pacific.

Gillion, K.L. 1977. The Fiji Indians: Challenge to European Dominance, 1920-1946. Canberra: Australian National University Press.

Gravelle, K. 2001. Good Governance in the South Pacific. Suva: University of the South Pacific.

Grynberg, R., D. Munro and M. White. 2002. Crisis: The Collapse of the National Bank of Fiji. Adelaide: Crawford House.

Kelsey, J. 2005. 'World Trade and Small Nations in the South Pacific Region.' The Kansas Journal of Law \& Public Policy, XVII, 11. pp. 247-306.

Lal, B. 1983. 'The 1982 Fiji National Election and its Aftermath.' USP Sociological Society Newsletter No. 5 (July).

Lal, B. 2003. 'Heartbreak Islands: Reflections on Fiji in Transition'. Asia Pacific Viewpoint, 44, 3. pp. 335-50. 
Lemke, T. 2000. 'Foucault, Governmentality, and Critique.' Paper presented at the Rethinking Marxism Conference, University of Amherst, September. pp. 1-17.

Lemke, T. "The Birth of Bio-Politics" — Michel Foucault's lecture at the College de France on Neo-Liberal Governmentality.' Mimeo.

Mara, R. K. 1997. The Pacific Way. Honolulu: University of Hawai'i Press.

Migdal, J. 2001. State in Society: Studying How States and Societies Transform and Constitute One Another. Cambridge: Cambridge University Press.

Naidu, V. 1988. 'State, Class and Politics in the South Pacific.' Unpublished D.Phil thesis, University of Sussex, Falmer.

Naidu, V. 2000a. 'Democracy and Governance in the South Pacific.' In E. Vasta (ed.), Citizenship, Community and Democracy, London and New York: Macmillan and St Martin's Press. pp. 45-68.

Naidu, V. 2000b. 'The Oxymoron of Security Forces in Island States.' Island Security Perceptions and Priorities Island Security Conference, Centre for Asia-Pacific Security Studies, Honolulu, Hawai'i.

Naidu, V. and R. Reddy. 2002. Na ghar ke, na ghat ke: ALTA and expiring land leases: Fijian farmers' perceptions of their future. Wollongong: Ford Foundation in association with Asia Pacific Migration Research Network, University of Wollongong.

Nation, J. 1978. 'Customs of Respect: The Traditional Basis of Fijian Communal Politics.' Development Studies Centre Monograph No. 14. Canberra: The Australian National University.

Naidu, V. 2003. 'Governance, Ethnicity and the State in Fiji: A Case of Diminishing Legitimacy.' Development Research Symposium, University of the South Pacific, Suva.

Norton, R. 1977. Race and Politics in Fiji. St Lucia: University of Queensland Press.

Niukula, P. n.d. The Three Pillars. Suva: Christian Writing Project.

Ould-Mey, M. 1999. 'The New Global Command Economy.' Environment and Planning D: Society and Space. 17, 2. pp. 155-180.

Premdass, R. 2001. 'Ethno-Racial Divisions and Governance: The Problem of Institutional Reform and Adaptation.' Paper for United Nations Research Institute for Social Development Conference on Racism and Public Policy, September, Durban, South Africa.

Powles, C. G. 1980. 'Law, Decision-Making and Legal Services in the Pacific Island States.' In R. T. Shand (ed.), Island States of the Pacific and Indian Ocean: Anatomy of Development, Canberra. 
Qalo, R. 1982. Divided We Stand. Suva: Institute of Pacific Studies.

Routledge, D. 1985. Matanitu: The struggle for power in early Fiji. Suva: University of the South Pacific.

Ratuva, S. 2000. 'Addressing Inequality? Economic Affirmative Action and Communal Capitalism in Post-Coup Fiji.' In A. H. Akram-Lodhi (ed.), Confronting Fiji Futures, Canberra: Asia Pacific Press. pp. 226-48.

Ratuva, S. 2002. 'Anatomizing the Vanua Complex: Intra-Communal Land Disputes and Implications on the Fijian Community.' Paper presented at South Pacific Land Tenure Conflicts Symposium, University of the South Pacific, Suva.

Reddy, M., B. C. Prasad, S. Kumar and V. Naidu. 2001. 'The 2002 Fiji National Budget: A Nation in Search of Economic Growth and Stability.' Working Paper No. 01/1. Suva: Centre for Development Studies, SSED, University of the South Pacific.

Reddy, M., V. Naidu and M. Manoranjan. 2002. 'Economic Cost of Human Capital Loss from Fiji: Implications for Sustainable Development.' Fifth International Conference of the Asia Pacific Migration Research Network, Naviti Resort, Fiji.

Sharpham, J. 2000. Rabuka of Fiji: The authorised biography of Major-General Sitiveni Rabuka. Rockhampton: Central Queensland University Press.

Simpson, S. 2003. 'Perceptions of Civil Society in Fiji.' Paper presented at the Commonwealth South Pacific Regional Consultation: Maximising Civil Society's Contribution to Democracy and Development, Auckland.

Sutherland, W. 1992. Beyond the Politics of Race: An Alternative History of Fiji to 1992. Political and Social Change Monograph no. 15. Canberra: Australian National University.

Tuimaleal'ifano, M. 2000. 'Veiqati Vaka Viti and the Fiji Islands Elections in 1999.' Journal of Pacific History, 35, 3. pp. 253-67.

Turner, M. and D. Hulme. 1997. Governance, Administration and Development: Making the State work. London: Macmillan.

\section{ENDNOTES}

${ }^{1}$ Before British colonial rule, contemporary Fiji was known as Viti and was divided into more than 40 polities, which formed wider alliances with each other. The latter, known as 'confederacies', waxed and waned over time depending on a range of factors. Some of these took proto-state forms. Warfare appeared to be endemic between 'tribal' groups. The late 19th century saw the emergence of three sizeable confederacies, conceived as 'matanitu' (government and state). These were Kubuna, which was led by Ratu Seru Cakobau, proclaimed by the settlers as Tui Viti (King of Fiji), Burebasaga and Tovata, which was united under the rulership of the Tongan aristocrat Ma'afu, who previously had ambitions to conquer the archipelago. None of these 'confederacies' had Fiji-wide control and the people of parts of the interior of the larger islands remained autonomous. It took a war of pacification by the British to subjugate them (Derrick 1946; Durutalo 1986). 
2 The Queen, venerated as 'Tui Viti' (the highest chief in the hierarchy of chieftainship), in her statement during the Vancouver Commonwealth Heads of Governments meeting, responded to the Taukei Movement and Rabuka's declaration of the republic, 'Her Majesty is sad to think that the ending of the Fijian allegiance to the Crown should have been brought about without the people of Fiji being given an opportunity to express their opinion in the proposal' (cited in Sharpham 2000: 136).

3 Sakeasi Butadroka, the ethno-nationalist leader, used the slogan 'Fiji for the Fijians', first coined by a white member of the colonial legislature in 1946. Following in the footsteps of Idi Amin of Uganda, he called for the repatriation of all 'Indians' to India. Surprisingly, it was known that there was some collaboration between the National Federation Party, led and supported by Indo-Fijians and the FNP (Premdass 1978).

4 The NFP had seen itself as an opposition-in-perpetuity party, unprepared to form government. The party took three days to decide who would lead it as Prime Minister. The Governor-General used a clause in the 1970 Constitution that gave him authority to appoint as Prime Minister the person who appeared to have the most support in Parliament. The Alliance leader, Ratu Mara, was to lose a vote of confidence, three months later; returning as Prime Minister after the second election of 1977 when the Alliance was returned by an overwhelming majority, thanks to major divisions within the NFP.

5 This included, among other things, the collapse of the National Bank of Fiji with the loss of more than \$F220 million in unsecured loans to prominent individuals and businesses.

${ }^{6}$ Ratu Sir Kamisese Mara's support for Mahendra Chaudhry as Prime Minister extended to persuading demurring Fijian Association Party (FAP) Members of Parliament. He was perceived to have carried out a behind-the-scenes campaign for FAP against the ruling Rabuka-led SVT (see Lal 1998: 21, for beginnings of the schism between Ratu Mara and Rabuka). The President's action in swearing in Chaudhry as Prime Minister redeemed him in the eyes of many FLP and NFP supporters who had regarded him as the person behind the first 1987 coup.

7 Prime Minister Mahendra Chaudhry's personal style; his slamming the door shut in further negotiating power sharing with the SVT; his marginalisation of his political ally, Apisai Tora; his government's naive policies relating to a Land Commission; meddling with affirmative action policies for ethnic Fijans; differential compensation for Indo-Fijian farmers $(\$ F 28,000)$ and support for ethnic Fijian landowners taking up sugarcane farming $(\$ 10,000)$; and apparent manipulation of chiefs as well as his alienation of the media: all these contributed to widening opposition.

8 The notion of 'paramountcy of Fijian interest' is said to emanate from the fact that chiefs unconditionally ceded the country to the British Monarch, Queen Victoria, and to the claim that on Fiji's political independence, sovereignty was returned to them. It has various meanings, which range from the recognition of indigenous Fijian interests in decision-making and at the symbolic level to ethnic supremacy extending to the Parliament and government comprising entirely ethnic Fijians.

9 The Methodist Church in rural Fijian districts has long preached against the idol-worshipping heathen 'Indians' (Radio NZ interview with Poseci Bune, October 24, 2005).

10 Owners of the land.

11 Durutalo (1986) had pointed to the nexus between 'ratuism, religion and rugby' in cementing ethnic solidarity and the leadership of chiefs.

12 Three factors have contributed to elements of ethnic Fijian political leadership resorting to destabilisation (apart from the well-publicised 'Indian-dominated government'): i) the absence of well paying jobs outside the Public Service for defeated politicians; ii) the significant difference between the salary and perks of office of a minister and a backbencher; iii) the personal ambitions of individuals concerned. For instance, Rabuka had applied unsuccessfully for three jobs outside the military before his mission to overthrow Dr Bavadra's Government and become the country's military 'strongman' (Sharpham 2000). 